\title{
Alternatif Pemanfaatan Sampah Organik Sebagai Konservasi Sumber Energi Listrik
}

\author{
Fitria Novita Sari ${ }^{1}$, Elsa Mita Lestari ${ }^{2}$, Marsela Novianti $^{3}$, Dyahasti Indrawari, dan I Ketut Mahardika \\ ${ }^{1}$ Pendidikan IPA, Universitas Jember.
}

Email :fnovita115@gmail.com

\begin{abstract}
The research article discussed the utilization of organic waste that always increases every year in line with the rate of population growth, therefore the article was prepared to review the utilization of organic waste as a form of conservation of electrical energy. The method in the research used is in the form of literature studies by collecting data from various sources or references relevant to the research conducted. The results of the literature study from several studies show that efforts to use organic waste derived from household waste, landfill waste, and organic waste in the market have the ability to be used for electrical energy sources and can be done energy conservation. The conclusion is that organic waste as an alternative to fossil fuels can be used as electrical energy, and that it can be used for energy conservation.
\end{abstract}

Keyword - Organic waste, Utilization, Electrical energy, Energy conservation.

Abstrak - Artikel penelitian yang dilakukan membahas tentang pemanfaatan sampah organik yang setiap tahunnya selalu terjadi peningkatan yang disebabkan laju pertumbuhan penduduk, oleh karena itu disusunlah artikel bertujuan untuk mengkaji pemanfaatan sampah organik sebagai bentuk konservasi energi listrik. Metode yang digunakan yaitu metode kajian berupa studi literatur dan untuk mengumpulkan data dari berbagai berbagai sumber atau referensi yang relevan dengan penelitian yang dilakukan. Hasil kajian literatur dari beberapa penelitian menunjukkan bahwa upaya pemanfaatan sampah yang berasal dari bahan organik seperti dari sampah yang dihasilkan oleh rumah tangga dan sampah hasil pembuangan akhir (TPA), serta sampah organik di pasar memiliki kemampuan digunakan untuk sumber energi listrik dan dapat dilakukan konservasi energi. Kesimpulan yaitu sampah organik sebagai alternatif dari bahan bakar energi fosil dapat digunakan sebagai energi listrik, sehingga dapat dimanfaatkan untuk konservasi energi.

Kata kunci - Sampah organik, Pemanfaatan, Energi listrik, Konservasi energi

\section{Pendahuluan}

Berdasarkan hasil siaran pers Kementerian Lingkungan Hidup dan Kehutanan pada tahun 2018 menyatakan bahwa persoalan sampah rumah tangga sedang menjadi pokok pembahasan. Sampah organik menjadi persoalan yang wajib untuk dilakukan pertanggungjawaban oleh ibu-ibu rumah tangga yang sebagian besarnya selalu mengeluarkan sampah dari rumah tangga yang bersangkutan. Sampah dari bahan organik maupun rumah tangga memperoleh sumber sampah terbesar sekitar 36\% lebih banyak dibandingkan dengan sampah tradisional $24 \%$. Berdasarkan presentasi tersebut didapatkan bahwa sekitar $57 \%$ sampah organik rumah tangga yang dihasilkan berupa sisa sayuran busuk, kayu, ranting, dan daun.

Peningkatan jumlah penduduk menyumbang tingginya sampah yang dihasilkan. Peningkatan tersebut tidak semata hanya karena dari tingginya jumlah penduduk, melainkan juga dari peningkatan ekonomi dan kegiatan penduduk [5]. Berdasarkan kajian oleh Sihite dalam Indah (2020) bahwa berdasarkan UU No. 18 tahun 2008 tentang pengelolaan sampah sudah tertulis untuk mewujudkan tingkat kesehatan pada masyarakat dan kebersihan terhadap lingkungan, juga pada pengolahan sampah yang menjadi sumber daya [6]. Pengolahan sampah di Indonesia saat ini menerapkan beberapa sistem atau metode pengolahan sampah, diantaranya menggunakan sistem tumpukan atau metode open dumping dan sistem timbunan atau metode sanitary landfill, dimana kedua metode ini merupakan metode konvensional.

Banyaknya sampah yang dihasilkan tidak menyurutkan berbagai pihak pengolahan untuk mengurangi timbunan sampah. Tujuan pengurangan sampah memberikan berbagai pihak dari masyarakat, pemerintah, maupun dunia usaha berkontribusi dalam mengurangi timbulan sampah. Upaya untuk mengurangi sampah dapat menerapkan prinsip 3R (Reduce, Reuse, Recycling). Prinsip yang sudah lama ada tidak memberikan efek besar terhadap timbulnya sampah yang semakin meningkat. Hal ini dikarenakan tingkat kesadaran masyarakat yang masih terbilang rendah [5].

Sampah memberikan permasalahan begitu mendasar bagi pemerintah. Sampah adalah sisa buangan yang tidak lagi dibutuhkan lagi oleh manusia yang berasal dari berbagai aktivitas yang menghasilkan barang berupa sampah berbentuk cair, padat, lumpur maupun gas. Berdasarkan permasalahan di atas, dapat diketahui bahwa perlunya pemanfaatan baru mengenai sampah khususnya sampah organik hasil rumah tangga untuk bisa dijadikan sebagai bahan baku dalam pembuatan energi listrik [8].

Penggunaan energi listrik sangat dibutuhkan masyarakat untuk kelangsungan hidup. Listrik menjadi 
sumber utama yang perlu adanya pengembangan berkelanjutan seperti penggunaan listrik menggunakan energi alternatif [12]. Pemanfaatan sampah adalah dengan melakukan pengolahan sampah organik melalui pembakaran gas yang dihasilkan sampah organik sehingga dapat menjadi energi listrik.

\section{Metode Penelitian}

Metode kajian penelitian ini menggunakan metode studi literatur dan menelaah beberapa artikel atau jurnal terkait, buku, dll terkait alternatif pemanfaatan sampah organik rumah tangga sebagai konservasi sumber energi listrik. Menurut Nazir (2014) penelitian menggunakan studi literatur adalah memahami atau menelaah secara teliti dan tekun pada keputusan yang dibutuhkan pada penelitian tersebut [9]. Penelitian menggunakan jenis data sekunder. Data yang telah diperoleh dikompilasi, kemudian hasil dari telaah ini akan digunakan untuk menganalisis, dan disimpulkan sehingga mendapatkan kesimpulan mengenai alternatif pemanfaatan sampah organik sebagai konservasi sumber energi listrik.

\section{Hasil dan Pembahasan}

\section{A. Konservasi Energi}

Konservasi adalah sebuah upaya pelestarian lingkungan untuk mencegah dari kerusakan maupun kepunahan dengan mempertahankan adanya setiap komponen-komponen yang ada di lingkungan agar dapat dimanfaatkan dalam jangka panjang hingga masa yang akan datang [11]. Menurut Rachman (2017) pengembalian atau konservasi yang dilakukan untuk melakukan suatu perbaikan menuju keadaan lebih baik dengan menggunakan metode atau cara yang konvensional atau cara tradisional sehingga dapat berfungsi sebagai bahan yang memberikan kondisi yang aman dari berbagai perusak. Lalu, konservasi energi adalah penggunaan pada sumber energi yang dilakukan secara efisien dengan tidak menghilangkan fungsi dari pemanfaatan energi dan tidak memberikan efek rendah terhadap ekonomi [14]. Sedangkan menurut Wicaksono dan Soebiyakto (2020) menyatakan bahwa konservasi energi merupakan perlakuan yang dilakukan secara teratur, terjadwal, dan konsisten sebagai bentuk suatu pelestarian pada energi dan memberikan kontribusi peningkatan terhadap efisien penggunaannya. Sehingga, konservasi energi merupakan upaya untuk mencegah lingkungan dari kerusakan dan kepunahan dengan melakukan pelestarian terhadap energi yaitu sebuah tindakan mengurangi ataupun mengganti energi tanpa merusak.

\section{B. Pengolahan Sampah organik}

Pengertian sampah menurut Rahayu dan Sukmono (2013) sampah adalah bahan yang dibuang karena sudah tidak dimanfaatkan lagi namun harus dikelola lagi untuk menjaga kesehatan masyarakat dan lingkungan [13]. Terdapat beberapa penggolongan sampah yaitu sampah yang berasal dari beberapa kegiatan. Kegiatan tersebut yaitu kegiatan rumah tangga, industri, pertanian, perdagangan, dan pembangunan. Sampah yang dihasilkan dari kegiatan ibu rumah tangga kebanyakan menghasilkan sampah organik. Sampah organik lainnya juga dihasilkan dari berbagai instansi seperti asrama, hotel, kantor, atau rumah sakit [8].

Pengolahan sampah dibagi menjadi beberapa tahapan yaitu

a. Pengumpulan

Tahap pertama, sampah dikumpulkan yang kemudian akan dikeringkan dengan di press menggunakan mesin press kemudian ditempatkan di ruangan yang sudah diatur suhunya, untuk sampah yang baru datang akan dipisahkan.

b. Pemindahan

Sampah yang telah di press dan dikeringkan selanjutnya akan dipindahkan ke Flail Mill.

c. Pengelompokan dan pemisahan

Tahapan selanjutnya yaitu pengelompokan sampah menggunakan beberapa alat. Alat yang digunakan yaitu seperti magnet separator. Dalam alat tersebut sampah diubah menjadi bahan bakar boiler yang berupa serbuk.

d. Perubahan dari sampah ke energi

Sampah pada tahap ini di masukan ke chamber atau ruang pembakaran.

e. Pengolahan biologi

Sampah basah secara biologis akan diubah menjadi kompos, karena sampah basah kurang ekonomis jika dijadikan sebagai bahan bakar

f. Pengolahan khusus

Pengolahan khusus ini digunakan untuk mengolah sampah khusus seperti plastik yang pengolahannya dicincang dan dijadikan pallate.

g. Pembuatan material

Dalam tahap ini pembuatan material ini sampah yang diolah menjadi pelet akan diubah menjadi bahan peralatan rumah tangga yang terbuat dari plastik.[8]

\section{Potensi Sampah Organik sebagai Sumber Listrik}




\begin{tabular}{|c|c|}
\hline $\begin{array}{l}\text { Annur, S., W. Kusmasari, R Wulandari, dan } \\
\text { Sumiati (2020) }\end{array}$ & $\begin{array}{l}\text { Reaktor biogas dari bahan sampah dapat berfungsi sebagai energi listrik } \\
\text { yang mampu menghidupkan lampu di sekitar TPA dan juga dapat } \\
\text { dimanfaatkan untuk bahan bakar kompor gas di dapur TPA. }\end{array}$ \\
\hline $\begin{array}{l}\text { Yulianasari, A. A. A. S. R. dan N. P. D. } \\
\text { Permanasuri (2020) }\end{array}$ & $\begin{array}{l}\text { Pengolahan sampah organik berpotensi sebagai pembangkit listrik } \\
\text { alternatif melalui pengembangan pilot project PLTG yang murah dan } \\
\text { ramah lingkungan. }\end{array}$ \\
\hline $\begin{array}{l}\text { Nurdiansah, T., Priyo, E., dan Kasiwi, A } \\
(2020) \text {. }\end{array}$ & $\begin{array}{l}\text { Terdapat berbagai pemanfaatan sampah salah satunya dimanfaatkan } \\
\text { sebagai sarana untuk PLTSa atau pembangkit listrik tenaga sampah yang } \\
\text { merupakan cara yang efektif untuk mengatasi permasalahan sampah. }\end{array}$ \\
\hline $\begin{array}{l}\text { Surma, U., A. Natio, S. Harahap, dan L. O. } \\
\text { M. Firman (2020) }\end{array}$ & $\begin{array}{l}\text { Sistem pembangkit sampah basah (sisa makanan) (PLTSa) dapat } \\
\text { menghasilkan gas metana sebesar } 110.924 \mathrm{~m} 3 / \text { hari, sehingga kemampuan } \\
\text { yang didapatkan untuk daya listrik sebesar 1,4 MW. }\end{array}$ \\
\hline Partha, C.G.I (2010) & $\begin{array}{l}\text { Sampah organik melalui teknologi gasifikasi dapat diolah menjadi bahan } \\
\text { bakar dalam bentuk gas hasil dari sampah organik yang dikelolah dengan } \\
\text { teknologi gasifikasi yang berbentuk gas yang dimanfaatkan untuk } \\
\text { menghasilkan sebuah energi listrik, sehingga dapat menggerakkan turbin. }\end{array}$ \\
\hline Hariningrum, R., dan Utomo, S.B (2020) & $\begin{array}{l}\text { Sampah organik dan anorganik memiliki banyak manfaat salah satunya } \\
\text { sebagai bahan bakar bakar untuk menghasilkan energi listrik pada PLTSa. }\end{array}$ \\
\hline $\begin{array}{l}\text { Sanfiyan, A.M.L., Ardiansyah, Y., dan } \\
\text { Maulana, E (2017). }\end{array}$ & $\begin{array}{l}\text { Biogas yang dihasilkan di TPA Penujah berupa sampah berbahan organik } \\
\text { yaitu sebanyak 4.098,923 m3/kg, biogas ini dapat menghasilkan energi } \\
\text { listrik sebesar 0,404 mWeH. }\end{array}$ \\
\hline $\begin{array}{l}\text { Priyono, K. D., K. Harismah, dan Qomarun } \\
(2020)\end{array}$ & $\begin{array}{l}\text { Pengolahan limbah yang dimanfaatkan untuk bahan baku pada energi } \\
\text { terbarukan dapat }\end{array}$ \\
\hline Allo, S. L. dan H. Widjasena (2019) & $\begin{array}{l}\text { Sampah organik yang diterapkan pada LFG (Landfil Gas) dapat } \\
\text { digunakan sebagai pemasok pembangkit listrik karena mengandung gas } \\
\text { metana sebesar } 55-57 \% \text {. }\end{array}$ \\
\hline Suhada, R. T. dan I. Al-Muhdy (2017) & $\begin{array}{l}\text { Pembangkit listrik tenaga sampah dapat memasok sebesar } 4 \% \text { untuk } \\
\text { kapasitas } 900 \text { kVA yang dapat digunakan pada } 40 \text { rumah tangga. }\end{array}$ \\
\hline $\begin{array}{l}\text { Lontoh, J. H., M. Rumbayan dan G. M. Ch. } \\
\text { Mangindaan (2017) }\end{array}$ & $\begin{array}{l}\text { Sampah organik yang dihasilkan dari pasar Pinasungkulan dapat } \\
\text { menghasilkan energi sebesar } 144.81 \mathrm{kWh} \text { untuk pembangkit listrik. }\end{array}$ \\
\hline
\end{tabular}


Arifin, M. Z. (2019)

Sampah organik dari TPA Banyuurip dapat menghasilkan sumber energi

sebesar 333,59 kW secara termokimia dan 764,13 kW secara biokimia,

sehingga memiliki persentase sebesar $61 \%$ sebagai sumber energi listrik.

Dari berbagai penelitian mengenai potensi sampah organik yang digunakan sebagai energi listrik memiliki kemampuan untuk menghasilkan energi listrik dan dapat dimanfaatkan untuk konservasi energi, sehingga dapat mengurangi penggunaan energi fosil untuk bahan bakar. Sampah organik tersebut dapat diperoleh dari sampah rumah tangga, sampah dari tempat pembuangan akhir (TPA) serta sampah organik di pasar.

\section{KESIMPULAN}

Berdasarkan kajian studi literatur yang telah dipaparkan menghasilkan bahwa dari beberapa penelitian terdahulu upaya untuk pemanfaatan sampah organik sebagai sumber energi listrik tersebut memiliki kemampuan untuk dilakukannya konservasi energi. konservasi energi yang dilakukan dengan memanfaatkan sampah organik yang diolah dengan cara mengumpulkan sampah, memindahkan sampah, pengelompokan dan pemisahan sampah, mengubah sampah ke energi, pengolahan biologi, pengolahan khusus, dan pembuatan material. Pemanfaatan sampah tersebut dapat mengurangi penggunaan energi fosil untuk bahan bakar. Sampah organik tersebut dapat diperoleh dari sampah rumah tangga, sampah dari TPA atau tempat pembuangan akhir serta sampah organik di pasar.

\section{DAFTAR ACUAN}

[1] Allo, S. L. dan H. Widjasena, "Studi potensi listrik tenaga sampah (PLTSa) pada tempat pembuangan akhir (TPA) makbon kota Sorong," Electro Luceat. vol. 5, no. 2, pp. 1-11, 2019

[2] Annur, S., W. Kusmasari, R. Wulandari, dan Sumiati, "Pengembangan biogas dari sampah untuk energi listrik dan bahan bakar kompor di TPA Cilowong, kota Cilowong, provinsi Banten," Jurnal Kuat (Keuangan Umum dan Akuntansi Terapan), vol.2, no.1, pp. 48-51, 2020.

[3] Arifin, M. Z, "Prospek inovasi pengelolaan sampah sebagai strategi mitigasi pemanasan global di kota Magelang," Jendela Inovasi Daerah, vol. 2, no. 2, pp. 13-31, 2019.

[4] Hariningrum, R., dan Utomo, S.B, "Pemanfaatan sampah sebagai energi alternatif pembangkit tenaga listrik di Semarang," Marine Science and Technology Journal, vol. 1, no.1, pp. 30-37, 2020.

[5] Hariyanto, "Pengelolaan sampah di Kota Semarang untuk menuju kota bersih," Jurnal Geografi, vol. 11, no. 2 , pp. $237-246,2014$
[6] Indah, A. B. R., S. B.Mulyadi., R. Hanafi., A.Asmal., F. Mardin., M. Rusman., I. Bakri., Nilda., D. R. Mudiastuti., S. Mangenre., I. Setiawan., S. Parenreng., M. A. Darmawan., K. Amar, dan N. I. Syamsul, "Sosialisasi pengelolaan sampah sebagai bahan bakar untuk pembangkit listrik tenaga sampah (PLTSa) dengan sistem Strategic Partner," Jurnal Teknologi Terapan untuk Pengabdian Masyarakat, vol. 3, no. 2, pp. 56-64, 2020.

[7] Lontoh, J. H., M. Rumbayan dan G. M. Ch. Mangindaan, "Analisa ekonomis pemanfaatan limbah organik sebagai pembangkit listrik tenaga gas (PLTG) pada pasar tradisional," Jurnal Teknik Elektro dan Komputer, vol. 6, no. 1, pp. 48-56, 2017.

[8] Monice dan Perinov, "Analisis potensi sampah sebagai bahan baku pembangkit listrik tenaga sampah (pltsa) di pekanbaru," Jurnal Sain, Energi, Teknologi \& Industri, vol. 1, no. 1, pp. 9-16, 2016.

[9] Nazir, M, Metode Penelitian, Jakarta: Ghalia Indonesia, 2014.

[10] Nurdiansah, T., Priyo, E., dan K. Aulia, "Implementasi Pembangkit Listrik Tenaga Sampah (PLTSa) sebagai solusi permasalahan sampah perkotaan; studi kasus di kota Surabaya," Jurnal Envirotek, vol. 12, no. 1, pp. 87-92, 2020.

[11] Nurhayati, D., "Penerapan tema konservasi pada perancangan taman wisata arboretum bambu parahyangan," Repository Tugas Akhir Arsitektur, vol. 3, no. 1, pp. 1-10, 2020.

[12] Partha, C.G.I, "Penggunaan sampah organik sebagai pembangkit listrik di tpa Suwung-Denpasar," Majalah Ilmiah Teknik Elektro, vol. 9, no. 2, pp. 152-158, 2010.

[13] Rahayu, D.E., dan Sukmono., "Kajian potensi pemanfaatan sampah organik pasar berdasarkan karakteristiknya (studi kasus Pasar Segiri Kota Samarinda)," Jurnal Sains dan Teknologi Lingkungan, Vol. 5, no. 2, pp. 77- 90, 2013.

[14] Safitra, A.G., dan M. D. A. P., "Konservasi energi sektor bangunan rumah sakit cempaka putih permata surabaya," Jurnal Technopreneur, Vol. 8, no. 2, pp. 97102, 2020.

[15] Suhada, R.T., dan I. Al-Mahdy, "Analisis potensi sampah sebagai sumber energi pembangkit listrik tenaga sampah dan produk kreatif untuk mendukung pariwisata (studi kasus di kepulauan seribu)," Jurnal Penelitian dan Aplikasi Sistem dan Teknik Industri, Vol. 9, no. 3, pp. 245-255, 2017.

[16] Surma, U., A. Natio, S. Harahap, dan L. O. M. Firman, "Analisa pemanfaatan sampah perkotaan untuk pembangkit listrik di TPA Ciniru kabupaten 
Kuningan," Teknobiz: Jurnal Ilmiah Program Studi Magister Teknik Mesin, vol. 10, no.1, pp. 7-12, 2020.

[17] Yulianasari, A. A. A. S. R. dan N. P. D. Permanasuri, "Sampah sebagai pembangkit listrik alternatif upaya pengembangan infrastruktur pusat kota lama Singaraja," Jurnal Anala, vol. 8, no. 2, pp. 33- 42, 2020. 